\title{
Green Marketing activities of four and five star hotels in Alexandria, Egypt \\ Nawal Morsi Zaki
}

High Institute of tourism and hotels (EGOTH) Alexandria

\begin{abstract}
The present study was formulated in order to evaluate various aspects (activities) of green marketing in $4 \& 5$ stars hotels in Alexandria. This study begun from October 2014 till February 2015, A prospective study was carried out to collect data from mangers, guests and chefs of $(n=9)$ four star hotel and $(n=6)$ five star hotels in Alexandria. The inclusion of environmental attributes into marketing activities as a part of environmental management system (Ems) was described; the results encourage the green marketing in hotels. We recommended that the government should institute rewards and tax benefits to advance the entrenchment of green practices in the hotel sector in Egypt especially in Alexandria city.
\end{abstract}

Keywords: Green marketing activities, 4\&5 star hotels, Environmental behavior.

\section{Introduction}

Green marketing can be defined as the management process responsible for identifying anticipating and satisfying the requirements of customers and society in a profitable and sustainable way .Hospitality industry all over the world has been increasingly getting worried about environmental issues. It has been specified that $75 \%$ of environment pollution caused by hotel industry was from over consuming energy, water and materials. The waste water, fume, and materials discharged during the operation would cause negative impacts on our environment. Therefore, without appropriate design and strategy, environment would be subjected to unwanted effects. The notion of environment protection and energy saving can induce green management into hotel facility construction ${ }^{(1)}$.

If hotel industry can adopt operation of the idea of green management, it can benefit environmental and ecological protection and diminish hotel operation cost. Furthermore, green marketing can appeal consumers who are in support of the identical idea, too. ${ }^{(2)}$

Some researches tried to underline how important is for a hotel to develop sustainable eco-marketing strategy, called green star hotel practices. These are environmental concerns, perceived customer effectiveness, and environmental friendly tourism behaviors ${ }^{(4)}$.

Global sustainable tourism council (GSTC) has 37 criteria's, based on an environment management system, e.g. water management, energy management, waste management, guest information kitchen (food and beverages), housekeeping, garden and beach area, interior and exterior appearance, organized around four main themes as effective sustainability planning, maximizing social and economic benefits to the local community, enhancing cultural heritage and reducing negative impacts on the environment. ${ }^{(7)}$

The marketing of a hotel as "green" or "sustainable" has emerged in recent years an important constituent of the promotion arsenal used by the lodging industry. The reason is simple. Both business and leisure travelers are increasingly looking for places that protect the environment as well as the health of guests. In addition, many meetings and convention planners now function under orders that call for, the selection of only those facilities that are sustainable. As a result, many different methods to promote sustainability have arisen. ${ }^{(8)}$

\section{Environmental management system}

The inclusion of environmental attributes into marketing activities has been discussed in a number of academic works in journals, governmental bodies, and in the popular press, it would appear that firms have taken a diverse range of approaches to using green marketing activities. Firms have undertaken green activities for various reasons. In some cases, firms have embraced environmental issues because they have recognized that they have a duty to behave responsibly. Many firms that have involved inorganic food production do so because of an emotive concern for environmental issues. ${ }^{(9)}$

An Environmental Management System (EMS) is a structured system designed to help organizations manage their environmental influences and improve environmental performance caused by their products, services and activities. The system requires the following steps to be completed: development of an environmental policy that reflects the organization's environmental commitments; appointment of a person (s) responsible for its coordination; identification of how the organization can interact with the environment and its actual and potential environmental impacts; identification of how the organization is committed to legal and other requirements relevant to environmental aspects; establishment of environmental objectives and targets, programs in which to achieve them; monitoring and measurement of the progress to achieve environmental objectives and targets; reviewing the system and environmental performance and continuous improvement of the organization's environmental performance ${ }^{(10)}$. 
So the aim of this study was:

1- To expose green marketing activities (attributes) of 4 and 5 star hotels in Alexandria, from the viewpoints of managers, guests, and chefs;

2-To evaluate the personal and organizational environmental behavior of green marketing managers in 4 \& 5 star hotels in Alexandria.

\section{Methodology}

This study begun from October 2014 till February 2015, data collected were from mangers, guests and chefs :( $\mathrm{n}=9$ ). From four star hotel and $(\mathrm{n}=6)$ from five star hotels in Alexandria. The survey methods used a self-administrated questionnaire which was distributed to a total sample of $(n=335)$ : managers $(n=15)$, guests $(n=272)$, Chefs $(n=28)$ and marketing managers (15). Five questionnaires were incomplete thus (330) were used for statistical analysis.

Two types of questionnaires were used

- The first questionnaire was designed to examine green marketing activities (attributed) from the viewpoints of managers, guests and chefs, it was divided into three parts

- The second questionnaire was designed to evaluate the personal and organizational behavior of green marketing on marketing managers in $4 \& 5$ star hotels in Alex; it was divided into three parts.

\section{Statistical analysis of the data:}

The gathered data was analyzed using IBM SPSS V.20.

\section{RESULTS}

Table (1): Distribution of the studied cases according to demographic data

\begin{tabular}{|c|c|c|c|c|c|c|}
\hline \multirow[t]{2}{*}{ Items } & \multicolumn{2}{|c|}{$\begin{array}{c}\text { Manager } \\
(\mathbf{n}=15)\end{array}$} & \multicolumn{2}{|c|}{$\begin{array}{c}\text { Guest } \\
(\mathrm{n}=272)\end{array}$} & \multicolumn{2}{|c|}{$\begin{array}{c}\text { Chefs } \\
(n=28)\end{array}$} \\
\hline & No. & $\%$ & No. & $\%$ & No. & $\%$ \\
\hline Gender & & & & & & \\
\hline Male & 13 & 86.7 & 124 & 45.6 & 27 & 96.4 \\
\hline Female & 2 & 13.3 & 148 & 54.4 & 1 & 3.6 \\
\hline Age & & & & & & \\
\hline $20-30$ & - & - & 152 & 55.9 & - & - \\
\hline $30-40$ & 9 & 60.0 & 62 & 22.8 & 3 & 10.7 \\
\hline $41-50$ & 5 & 33.3 & 24 & 8.8 & 4 & 14.3 \\
\hline $51-60$ & 1 & 6.7 & 16 & 5.9 & 16 & 57.1 \\
\hline Above 60 & - & - & 18 & 6.6 & 5 & 17.9 \\
\hline Educational level & & & & & & \\
\hline Primary school & - & - & - & - & 1 & 3.6 \\
\hline High school & - & - & - & - & 5 & 17.9 \\
\hline Under graduated & - & - & 36 & 13.2 & - & - \\
\hline Graduated & 8 & 53.3 & 126 & 46.3 & 22 & 78.6 \\
\hline Post graduate & 7 & 46.7 & 108 & 39.7 & - & - \\
\hline Others & - & - & 2 & 0.7 & - & - \\
\hline Current Position & & & & & & \\
\hline Manager & 12 & 80.0 & - & - & - & - \\
\hline General manager & 3 & 20.0 & - & - & - & - \\
\hline Student & - & - & 80 & 29.4 & - & - \\
\hline Free business & - & - & 8 & 2.9 & - & - \\
\hline In the field of tourism and hotels & - & - & 44 & 16.2 & - & - \\
\hline In the field of university education & - & - & 100 & 36.8 & - & - \\
\hline Retired & - & - & 8 & 2.9 & - & - \\
\hline Others & - & - & 32 & 11.8 & - & - \\
\hline Teacher & - & - & - & - & - & - \\
\hline Sales & - & - & - & - & - & - \\
\hline
\end{tabular}


Green Marketing activities of four and five star hotels in Alexandria, Egypt

\begin{tabular}{||l|c|c|c|c|c|c||}
\hline Chef & - & - & - & - & 5 & 17.9 \\
Souse chefs & - & - & - & - & 11 & 39.3 \\
Executive chefs & - & - & - & - & 12 & 42.9 \\
\hline Location & 9 & 60.0 & - & - & 12 & 42.9 \\
$\quad$ Star hotel & 6 & 40.0 & - & - & 16 & 57.1 \\
5 Star hotel & & & & & & \\
\hline Number of rooms & 9 & 60.0 & - & - & - & - \\
$100-200$ & 4 & 26.7 & - & - & - & - \\
$201-300$ & 0 & 0.0 & - & - & - & - \\
$301-400$ & 2 & 13.3 & - & - & - & - \\
Above 400 & 1 & 6.7 & - & - & - & - \\
\hline Number of employees & 7 & 46.7 & - & - & - & - \\
$50-100$ & 2 & 13.3 & - & - & - & - \\
$101-150$ & 3 & 20.0 & - & - & - & - \\
$151-200$ & 2 & 13.3 & - & - & - & - \\
$201-250$ & & & & & \\
Above 250 &
\end{tabular}

Table (2): Distribution of hotels according to water management, energy management and air quality

\begin{tabular}{|c|c|c|c|c|c|c|c|c|c|c|c|c|}
\hline \multirow{4}{*}{ Green marketing activities (attributes) } & \multicolumn{8}{|c|}{ Location } & \multirow{2}{*}{\multicolumn{4}{|c|}{$\begin{array}{l}\text { Total } \\
(\mathbf{n}=\mathbf{1 5})\end{array}$}} \\
\hline & \multicolumn{4}{|c|}{$\begin{array}{c}\text { 4 Star hotel } \\
(n=9)\end{array}$} & \multicolumn{4}{|c|}{$\begin{array}{c}5 \text { Star hotel } \\
(\mathbf{n}=6)\end{array}$} & & & & \\
\hline & \multicolumn{2}{|c|}{\begin{tabular}{l|l} 
Yes \\
\end{tabular}} & \multicolumn{2}{|c|}{ No } & \multicolumn{2}{|c|}{\begin{tabular}{l|l} 
Yes \\
\end{tabular}} & \multicolumn{2}{|c|}{ No } & \multicolumn{2}{|c|}{ Yes } & \multicolumn{2}{|c|}{ No } \\
\hline & No. & $\%$ & No. & $\%$ & No. & $\%$ & No. & $\%$ & No. & $\%$ & No. & $\%$ \\
\hline $\begin{array}{l}\text { Green activity (water management) } \\
\text { Is hotel using water-saving device as aerator } \\
\text { in their taps and showers }\end{array}$ & 3 & 33.3 & 6 & 66.7 & 3 & 50.0 & 3 & 50.0 & 6 & 40.0 & 9 & 60.0 \\
\hline Is hotel using waste & 9 & 100.0 & 0 & 0.0 & 6 & 100.0 & 0 & 0.0 & 15 & 100.0 & 0 & 0.0 \\
\hline $\begin{array}{l}\text { Is hotel using waterless urinals or photocell } \\
\text { urinals in public toilets (photocell taps: are } \\
\text { being all hotels in public toilets but not in } \\
\text { rooms) }\end{array}$ & 0 & 0.0 & 9 & 100.0 & 0 & 0.0 & 6 & 100.0 & 0 & 0.0 & 15 & $\begin{array}{c}100 . \\
0\end{array}$ \\
\hline $\begin{array}{l}\text { Are there some small cards on the towels with } \\
\text { a phrase" will be used again "written on them } \\
\text { (sheets changed only if requested for stays up } \\
\text { to three nights) }\end{array}$ & 2 & 22.2 & 7 & 77.8 & 3 & 50.0 & 3 & 50.0 & 5 & 33.3 & 10 & 66.7 \\
\hline $\begin{array}{l}\text { Is hotel using } \mathrm{p} \\
\text { kitchens }\end{array}$ & 1 & 11.1 & 8 & 88.9 & 3 & 50.0 & 3 & 50.0 & 4 & 26.7 & 11 & 73.3 \\
\hline $\begin{array}{l}\text { Is hotel using low flow shower heads in the } \\
\text { room }\end{array}$ & 3 & 33.3 & 6 & 66.7 & 3 & 50.0 & 3 & 50.0 & 6 & 40.0 & 9 & 60.0 \\
\hline Green activity (energy management) & & & & & & & & & & & & \\
\hline $\begin{array}{l}\text { Is hotel using an energy- saving lighting } \\
\text { system in lobbies, rooms, open areas, offices, } \\
\text { kitchens and laundry }\end{array}$ & 5 & 55.6 & 4 & 44.4 & 1 & 16.7 & 5 & 83.3 & 6 & 40.0 & 9 & 60.0 \\
\hline $\begin{array}{l}\text { Is hotel benefiting from the sunlight in } \\
\text { restaurants and lobbies }\end{array}$ & 7 & 77.8 & 2 & 22.2 & 5 & 83.3 & 1 & 16.7 & 12 & 80.0 & 3 & 20.0 \\
\hline $\begin{array}{l}\text { Is hotel using motion sensor lamps in public } \\
\text { toilets.(occupancy sensors used to control } \\
\text { lighting in the room) }\end{array}$ & 2 & 22.2 & 7 & 77.8 & 2 & 33.3 & 4 & 66.7 & 4 & 26.7 & 11 & 73.3 \\
\hline $\begin{array}{l}\text { Is hotel putting posters about energy saving in } \\
\text { rooms and all of them have automatic heating } \\
\text { and cooling systems, energy saving } \\
\text { refrigerators and other electronic devices and } \\
\text { machines in rooms, kitchens and laundry }\end{array}$ & 5 & 55.6 & 4 & 44.4 & 6 & 100.0 & 0 & 0.0 & 11 & 73.3 & 4 & 26.7 \\
\hline Is hotel using double- glass windows in the & 2 & 22.2 & 7 & 77.8 & 2 & 33.3 & 4 & 66.7 & 4 & 26.7 & 11 & \\
\hline
\end{tabular}


Nawal Morsi Zaki

whole hotel to control heat leak

Is hotel using integrated office equipment's such as printer, scanner, copy and fax, all in one, devices that do not consume energy separately

\section{Green activity}

(increasing the air quality in hotels). Are armchairs, beds and carpets are being cleaned by expert cleaning companies periodically to clean mites and allergens Is hotel using environmental- friendly paints and wallpapers in rooms and lobbies.(especially water-based paints that are highly important to protect the environment Is hotel assigning smoking rooms Is hotel not allowing personnel to smoke within work hours

Is there special instructions for smoking such as only at private area, in disco or balconies

\begin{tabular}{|l|l|l|l|l|l|l|l|l|l|l|l||}
\hline 6 & 66.7 & 3 & 33.3 & 2 & 33.3 & 4 & 66.7 & 8 & 53.3 & 7 & 46.7 \\
\hline 7 & 77.8 & 2 & 22.2 & 5 & 83.3 & 1 & 16.7 & 12 & 80.0 & 3 & 20.0 \\
\hline 7 & 77.8 & 2 & 22.2 & 6 & 100.0 & 0 & 0.0 & 13 & 86.7 & 2 & 13.3 \\
\hline 9 & 100.0 & 0 & 0.0 & 6 & 100.0 & 0 & 0.0 & 15 & 100.0 & 0 & 0.0 \\
\hline 7 & 77.8 & 2 & 22.2 & 3 & 50.0 & 3 & 50.0 & 10 & 66.7 & 5 & 33.3 \\
\hline 2 & 22.2 & 7 & 77.8 & 2 & 33.3 & 4 & 66.7 & 4 & 26.7 & 11 & 73.3 \\
\hline
\end{tabular}

Table (3): Distribution of hotels according to waste management and recycling

\begin{tabular}{|c|c|c|c|c|c|c|c|c|c|c|c|c|}
\hline \multirow{4}{*}{$\begin{array}{c}\text { Green activity } \\
\text { (waste management and recycling) }\end{array}$} & \multicolumn{8}{|c|}{ Location } & \multirow{2}{*}{\multicolumn{4}{|c|}{$\begin{array}{c}\text { Total } \\
(\mathbf{n}=15)\end{array}$}} \\
\hline & \multicolumn{4}{|c|}{$\begin{array}{l}4 \text { Star hotel } \\
\quad(n=9)\end{array}$} & \multicolumn{4}{|c|}{$\begin{array}{l}5 \text { Star hotel } \\
\quad(n=6)\end{array}$} & & & & \\
\hline & \multicolumn{2}{|c|}{ Yes } & \multicolumn{2}{|c|}{ No } & \multicolumn{2}{|c|}{ Yes } & \multicolumn{2}{|c|}{ No } & \multicolumn{2}{|c|}{ Yes } & \multicolumn{2}{|c|}{ No } \\
\hline & No. & $\%$ & No. & $\%$ & No. & $\%$ & No. & $\%$ & No. & $\%$ & No. & $\%$ \\
\hline $\begin{array}{l}\text { Is there recycling- bins place in open areas and } \\
\text { visitors can reach them easily }\end{array}$ & 2 & 22.2 & 7 & 77.8 & 2 & 33.3 & 4 & 66.7 & 4 & 26.7 & 11 & 73.3 \\
\hline Is hotel has recycling-bins in rooms & 1 & 11.1 & 8 & 88.9 & 0 & 0.0 & 6 & 100.0 & 1 & 6.7 & 14 & 93.3 \\
\hline Is there recycling- bins in offices & 1 & 11.1 & 8 & 88.9 & 0 & 0.0 & 6 & 100.0 & 1 & 6.7 & 14 & 93.3 \\
\hline $\begin{array}{l}\text { To reducing paper usage, let visitor to do their } \\
\text { check- in and check -out transactions via on- } \\
\text { line }\end{array}$ & 5 & 55.6 & 4 & 44.4 & 1 & 16.7 & 5 & 83.3 & 6 & 40.0 & 9 & 60.0 \\
\hline $\begin{array}{l}\text { Are hotels scanning identity cards and } \\
\text { passports of visitors and they don't have any } \\
\text { paper copy to keep at registration }\end{array}$ & 6 & 66.7 & 3 & 33.3 & 1 & 16.7 & 5 & 83.3 & 7 & 46.7 & 8 & 53.3 \\
\hline $\begin{array}{l}\text { Is hotel using soaps and foams kept in boxes on } \\
\text { the wall in public toilets. And when they are } \\
\text { finished, they can be filled again and boxes } \\
\text { reused easily. }\end{array}$ & 8 & 88.9 & 1 & 11.1 & 5 & 83.3 & 1 & 16.7 & 13 & 86.7 & 2 & 13.3 \\
\hline $\begin{array}{l}\text { Is hotel using disposable small bottles for } \\
\text { shampoo and soaps (Refillable shampoo } \\
\text { dispensers instead of individual bottles) }\end{array}$ & 6 & 66.7 & 3 & 33.3 & 1 & 16.7 & 5 & 83.3 & 7 & 46.7 & 8 & 53.3 \\
\hline
\end{tabular}


Is hotel putting small posters on the wall in rooms and lobbies to inform visitors about management and reducing wastes

Is hotel using reusable table clothes

\begin{tabular}{|l|l|l|l|l|l|l|l|l|l|l|l||}
1 & 11.1 & 8 & 88.9 & 0 & 0.0 & 6 & 100.0 & 1 & 6.7 & 14 & 93.3 \\
\hline 8 & 88.9 & 1 & 11.1 & 5 & 83.3 & 1 & 16.7 & 13 & 86.7 & 2 & 13.3 \\
\hline
\end{tabular}


Table (4): Distribution of the studied cases according to chef management in the kitchen

\begin{tabular}{|c|c|c|c|c|c|c|c|c|c|c|c|c|}
\hline \multirow{4}{*}{ Chef } & \multicolumn{8}{|c|}{ Location } & \multirow{2}{*}{\multicolumn{4}{|c|}{ Total }} \\
\hline & \multicolumn{4}{|c|}{$4 \operatorname{star}(n=12)$} & \multicolumn{4}{|c|}{$5 \operatorname{star}(n=16)$} & & & & \\
\hline & \multicolumn{2}{|c|}{ Yes } & \multicolumn{2}{|c|}{ No } & \multicolumn{2}{|c|}{ Yes } & \multicolumn{2}{|c|}{ No } & \multicolumn{2}{|c|}{ Yes } & \multicolumn{2}{|c|}{ No } \\
\hline & No. & $\%$ & No. & $\%$ & No. & $\%$ & No. & $\%$ & No. & $\%$ & No. & $\%$ \\
\hline $\begin{array}{l}1 \text { - Does hotel collects the hotel's waste } \\
\text { kitchen oil and sells it to companies } \\
\text { producing biodiesel and other waste-oil } \\
\text { products }\end{array}$ & 9 & 75.0 & 3 & 25.0 & 11 & 68.0 & 5 & 31.2 & 20 & 71.4 & 8 & 28.6 \\
\hline $\begin{array}{l}\text { 2- Do chefs buy \& using green product as } \\
\text { organic groceries. Are chefs using green } \\
\text { organic vegetables and fruits in preparing } \\
\text { the menu? }\end{array}$ & 2 & 16.7 & 10 & 83.3 & 4 & 25.0 & 12 & 75.0 & 6 & 21.4 & 22 & 78.6 \\
\hline $\begin{array}{l}3 \text { - Are chefs Appling recycling for plastic, } \\
\text { card board, cans and bottles by putting each } \\
\text { in separate boxes. }\end{array}$ & 6 & 50.0 & 6 & 50.0 & 4 & 25.0 & 12 & 75.0 & 10 & 35.7 & 18 & 64.3 \\
\hline $\begin{array}{l}\text { 4- Are chefs Appling recycling for organic } \\
\text { garbage? }\end{array}$ & 6 & 50.0 & 6 & 50.0 & 1 & 6.3 & 15 & 93.8 & 7 & 25.0 & 21 & 75.0 \\
\hline $\begin{array}{l}5 \text { - Are chefs using low flow water fixtures } \\
\text { in kitchen? }\end{array}$ & 2 & 16.7 & 10 & 83.3 & 5 & 31.2 & 11 & 68.8 & 7 & 25.0 & 21 & 75.0 \\
\hline 6- Do chefs Re-use plastic bags in kitchen? & 1 & 8.3 & 11 & 91.7 & 0 & 0.0 & 16 & 100.0 & 1 & 3.6 & 27 & 96.4 \\
\hline $\begin{array}{l}7 \text { - Do chefs use energy saving light bulbs } \\
\text { in kitchen? }\end{array}$ & 9 & 75.0 & 3 & 25.0 & 11 & 8.8 & 5 & 31.2 & 20 & 71.4 & 8 & 28.6 \\
\hline $\begin{array}{l}8 \text { - Do chefs prepare appropriate amounts } \\
\text { of food for conferences, serve high quality } \\
\text { leftovers in the employee cafeteria }\end{array}$ & 11 & 91.7 & 1 & 8.3 & 16 & $\begin{array}{c}100 . \\
0\end{array}$ & 0 & 0.0 & 27 & 96.4 & 1 & 3.6 \\
\hline $\begin{array}{l}9 \text { - Do chefs donate excess safe, food to } \\
\text { Blanchet house, a local shelter applied. }\end{array}$ & 9 & 75.0 & 3 & 25.0 & 9 & 56.3 & 7 & 43.7 & 18 & 64.3 & 10 & 35.7 \\
\hline
\end{tabular}


Table (5): Distribution of the studied cases according to environmental friendly attributes (in guest room) - Likert scale

\begin{tabular}{|c|c|c|c|c|c|c|c|c|c|c|c|}
\hline \multirow[t]{2}{*}{ Environmentally friendly attributes } & \multicolumn{2}{|c|}{$\begin{array}{c}\text { Strongly } \\
\text { agree }\end{array}$} & \multicolumn{2}{|c|}{ Agree } & \multicolumn{2}{|c|}{ Neutral } & \multicolumn{2}{|c|}{ Disagree } & \multicolumn{2}{|c|}{$\begin{array}{l}\text { Strongly } \\
\text { disagree }\end{array}$} & \multirow{2}{*}{ Mean \pm SD } \\
\hline & No & $\%$ & No & $\%$ & No & $\%$ & No & $\%$ & No & $\%$ & \\
\hline $\begin{array}{l}\text { Use of energy saving light bulbs in the } \\
\text { sleeping area of the room }\end{array}$ & 185 & 58.1 & 78 & 28.7 & 24 & 8.8 & 12 & 4.4 & 0 & 0.0 & $4.40 \pm 0.83$ \\
\hline $\begin{array}{l}\text { Use of energy saving light bulbs in the } \\
\text { guest bath room }\end{array}$ & 120 & 44.1 & 96 & 35.3 & 26 & 9.6 & 22 & 8.1 & 8 & 2.9 & $4.32 \pm 0.96$ \\
\hline Use of Low Flow Toilets in the room & 78 & 28.7 & 66 & 24.3 & 46 & 16.9 & 60 & 22.1 & 22 & 8.1 & $4.19 \pm 1.08$ \\
\hline Use of Low Flow Faucets in the room & 78 & 28.7 & 70 & 25.7 & 44 & 16.2 & 56 & 20.6 & 24 & 8.8 & $4.10 \pm 1.06$ \\
\hline $\begin{array}{l}\text { Use of Low Flow Showerheads in the } \\
\text { room }\end{array}$ & 50 & 18.4 & 68 & 25.0 & 46 & 16.9 & 62 & 22.8 & 46 & 16.9 & $4.09 \pm 1.05$ \\
\hline $\begin{array}{l}\text { Refillable Soap Dispensers instead of } \\
\text { bars of soap }\end{array}$ & 120 & 44.1 & 88 & 32.4 & 42 & 15.4 & 12 & 4.4 & 10 & 3.7 & $4.07 \pm 1.07$ \\
\hline $\begin{array}{l}\text { Refillable Shampoo Dispensers instead } \\
\text { of individual bottles }\end{array}$ & 118 & 43.4 & 92 & 33.8 & 34 & 12.5 & 18 & 6.6 & 10 & 3.7 & $3.45 \pm 1.33$ \\
\hline $\begin{array}{l}\text { Sheets Changed only if requested (for } \\
\text { stays up to three nights) }\end{array}$ & 66 & 24.3 & 82 & 30.1 & 34 & 12.5 & 52 & 19.1 & 38 & 14.0 & $3.43 \pm 1.32$ \\
\hline $\begin{array}{l}\text { Key Cards that turn power to the room } \\
\text { on and off }\end{array}$ & 156 & 57.4 & 72 & 26.5 & 24 & 8.8 & 16 & 5.9 & 4 & 1.5 & $3.32 \pm 1.39$ \\
\hline $\begin{array}{l}\text { Occupancy Sensors used to control } \\
\text { lighting in the room }\end{array}$ & 144 & 52.9 & 70 & 25.7 & 34 & 12.5 & 14 & 5.1 & 10 & 3.7 & $3.05 \pm 1.38$ \\
\hline
\end{tabular}


Table (6): Distribution of the studied cases according to Personal environmental behaviors; marketing managers indicate their agreement or disagreement (Likert-scale)

\begin{tabular}{|c|c|c|c|c|c|c|c|c|c|c|c|}
\hline \multirow[t]{2}{*}{ Statements } & \multicolumn{2}{|c|}{$\begin{array}{c}\text { Strongly } \\
\text { agree }\end{array}$} & \multicolumn{2}{|c|}{ Agree } & \multicolumn{2}{|c|}{ Neutral } & \multicolumn{2}{|c|}{ Disagree } & \multicolumn{2}{|c|}{$\begin{array}{l}\text { Strongly } \\
\text { disagree }\end{array}$} & \multirow{2}{*}{$\begin{array}{l}\text { Mean } \pm \\
\text { SD. }\end{array}$} \\
\hline & No. & $\%$ & No. & $\%$ & No. & $\%$ & No. & $\%$ & No. & $\%$ & \\
\hline $\begin{array}{l}\text { 1-We are approaching the limit of } \\
\text { the number of people the earth can } \\
\text { support }\end{array}$ & 7 & 46.7 & 7 & 46.7 & 1 & 6.7 & 0 & 0.0 & 0 & 0.0 & $4.40 \pm 0.63$ \\
\hline $\begin{array}{l}\text { 2-The balance of nature is very } \\
\text { delicate and easily gets upset }\end{array}$ & 2 & 13.3 & 2 & 13.3 & 4 & 26.7 & 4 & 26.7 & 3 & 20.0 & $2.73 \pm 1.33$ \\
\hline $\begin{array}{l}\text { 3-Plants and animals have as much } \\
\text { right as humans to exist }\end{array}$ & 0 & 0.0 & 1 & 6.7 & 3 & 20.0 & 6 & 40.0 & 5 & 33.3 & $2.0 \pm 0.93$ \\
\hline $\begin{array}{l}\text { 4-If things continue on their present } \\
\text { course, we will soon experience a } \\
\text { major ecological catastrophe }\end{array}$ & 2 & 13.3 & 5 & 33.3 & 0 & 0.0 & 3 & 20.0 & 5 & 33.3 & $2.73 \pm 1.58$ \\
\hline $\begin{array}{l}\text { 5-Human ingenuity will ensure that } \\
\text { we don't make the earth unlivable }\end{array}$ & 7 & 46.7 & 5 & 33.3 & 3 & 20.0 & 0 & 0.0 & 0 & 0.0 & $4.27 \pm 0.80$ \\
\hline $\begin{array}{l}\text { 6-The balance of nature is strong } \\
\text { enough to cope with the impacts of } \\
\text { modern industrial nations }\end{array}$ & 10 & 66.7 & 5 & 33.3 & 0 & 0.0 & 0 & 0.0 & 0 & 0.0 & $4.67 \pm 0.49$ \\
\hline $\begin{array}{l}\text { 7-The so-called ecological crises } \\
\text { facing human-kind have been } \\
\text { greatly exaggerated }\end{array}$ & 0 & 0.0 & 6 & 40.0 & 7 & 46.7 & 2 & 13.3 & 0 & 0.0 & $3.27 \pm 0.70$ \\
\hline $\begin{array}{l}\text { 8-Human were meat to rule the rest } \\
\text { of nature }\end{array}$ & 11 & 73.3 & 3 & 20.0 & 0 & 0.0 & 1 & 6.7 & 0 & 0.0 & $4.60 \pm 0.83$ \\
\hline
\end{tabular}


Table (7): Distribution of the studied cases according to organizational environmental behaviors (OEVs), guests indicate their degree of agreement or disagreement (likert scale)

\begin{tabular}{|c|c|c|c|c|c|c|}
\hline Statements & $\begin{array}{l}\text { Strongly } \\
\text { disagree }\end{array}$ & Disagree & Neutral & Agree & $\begin{array}{c}\text { Strongly } \\
\text { agree }\end{array}$ & Mean \pm SD \\
\hline $\begin{array}{l}\text { 1-Hotels should simply comply with } \\
\text { government regulations to be more } \\
\text { responsible. }\end{array}$ & 26.1 & 34.8 & 21.7 & 10.9 & 6.5 & $2.37 \pm 1.18$ \\
\hline $\begin{array}{l}\text { 2-Hotel occupancy levels are more } \\
\text { important than environmental issues. }\end{array}$ & 47.8 & 47.8 & 4.3 & 0.0 & 0.0 & $1.57 \pm 0.58$ \\
\hline $\begin{array}{l}\text { 3-It is better to ignore environmental issues } \\
\text { (e.g. linen programmer) that could impact } \\
\text { guests' experiences, as hotels are driven by } \\
\text { market preferences. }\end{array}$ & 41.3 & 45.7 & 4.3 & 6.5 & 2.2 & $1.83 \pm 0.95$ \\
\hline $\begin{array}{l}\text { 4-Environmental managementlmarketing } \\
\text { in hotel industry is a public relations } \\
\text { invention to name cordial relations with } \\
\text { stakeholders. }\end{array}$ & 50.0 & 34.8 & 10.9 & 2.2 & 2.2 & $1.72 \pm 0.91$ \\
\hline $\begin{array}{l}\text { 5-Environmental responsiveness is the right } \\
\text { thing to do for the sustainability of hotels. }\end{array}$ & 28.3 & 37.0 & 19.6 & 13.0 & 2.2 & $2.24 \pm 1.08$ \\
\hline $\begin{array}{l}\text { 6-Governmental intervention is important } \\
\text { to encourage hotels to be environmentally } \\
\text { friendly }\end{array}$ & 6.5 & 32.6 & 15.2 & 39.1 & 6.5 & $3.07 \pm 1.12$ \\
\hline $\begin{array}{l}\text { 7-A hotel should wait and see how } \\
\text { competitors are benefiting before } \\
\text { introducing environmental strategies. }\end{array}$ & 17.4 & 21.7 & 19.6 & 26.1 & 15.2 & $3.0 \pm 1.35$ \\
\hline $\begin{array}{l}\text { 8-Hotels do not have the right to damage } \\
\text { the environment just to satisfy their needs. }\end{array}$ & 23.9 & 28.3 & 10.9 & 23.9 & 13.0 & $2.74 \pm 1.41$ \\
\hline $\begin{array}{l}9 \text { - Human will eventually learn enough } \\
\text { about how nature works to be able to } \\
\text { control it. }\end{array}$ & 28.3 & 23.9 & 17.4 & 23.9 & 6.5 & $2.57 \pm 1.31$ \\
\hline
\end{tabular}




\section{DISCUSSION}

This study was done to identify green marketing activities of four and five star hotels in Alexandria and to evaluate the dimensions of personal and organizational (marketing managers) environmental behavior.

All hotels use waterless urinals while $22.2 \%$ of 4 star hotel and $50 \%$ of five star hotels, have some small cards on the towels "will be used again", so they don't use disposable towels in rooms but after using by the guest they are cleaned with high-tech washing technologies and used again; if guests request to change their towels and bed sheet they should put them on the floor. This is an important activity to avoid unnecessary water utilization. $11.1 \%$ of 4 star hotel and $50 \%$ of 5 star hotels have photocell tap systems also in kitchens. to save water. Regarding energy management activities, about half of 4 star hotels and $16.7 \%$ of 5 star hotels use energy saving lighting in lobbies, rooms, open areas, offices, kitchens and laundry. Most of the hotels benefit from the sun light in restaurants and lobbies thereby reduce lighting expenditures. $22.2 \%$ of 4 star hotels and $33.3 \%$ of 5 star hotels have a double glass window system that allows control heat leak. $66.7 \%$ of 4 star hotels and $33.3 \%$ of 5 star hotels are using integrated office equipment such as printer, scanner, copy and fax, all in one device, so they don't consume energy separately (Table2).

Regarding increasing the air quality in hotels (Table2). Most hotels of the both 4 and 5 star clean armchairs, bed and carpets from mites and allergens by expert cleaning companies periodically and use environmental friendly paints and walls papers in rooms and lobbies. hours $^{\text {All }}$.

All hotels assign smoking area and rooms, also smoking is not allowed for personnel within the work

The results further show the distribution of hotels according to waste management and recycling subject; only $22.2 \%$ of 4 star hotels and $33.3 \%$ of 5 star hotels place recycling-bins in open area and guests can reach them easily. The lowest percentage $11.1 \%$ in 4 star hotels only has recycling-bins in rooms or offices.

Reducing paper usage is one of the most important subjects in waste management (Table3). 55.6\% of 4 star hotels and $16.7 \%$ of 5 star hotels let guests to do their check in and check - out via on - line. The highest percentage $88.9 \%$ of 4 star hotels and $83.3 \%$ of 5 star hotels use soaps and foams and reusable table clothes.

The highest percentage, $91.7 \%$ of chefs in 4 star hotels and $100 \%$ of chefs in 5 star hotels collect hotel's kitchen waste oil and sell it to companies producing biodiesel and other waste- oil products. Also the majority of them (75\% and 68\% respectively) use energy-saving bulbs (Table4).

The use of energy saving light bulbs in the sleeping area of the room, and of key cards that turn power to the room on and off was of the highest mean of all the attributes $(M=4.40,4.32)$ respectively. This sends a message to hoteliers and hotel developers that guests will accept such attributes in the hotel room. The lowest mean score was for the use of low flow shower heads in the room followed by sheets changed only if requested for stays up to three nights. ( $M=3.05,3.32$ respectively). The three attributes that seemed to raise some doubt were the use of refillable shampoo and soap dispensers, as well as the use of the low flow shower heads dispensers ${ }^{(12)}$ (Table5).

Table (6) shows that most strongly agreed responses $(73.3 \%)$ were to the statement, humans were meet to rule the rest of nature, where $(M=4.60)$, also the most strongly agreed responses $(66.7 \%)$ were to the statement: " the balance of nature is strong enough to cope with the impacts of modern industrial nations", $(M=4.67)$, also both the statements, "we are approaching the limit of the number of people the earth can support" and " human ingenuity will ensure that we don't make the earth unlivable", showed 46.7\% (M= $4.40), 46.7 \%(\mathrm{M}=4.27)$ respectively..

In practice, personal environmental behavior did not explain a portion of the overall variance in marketing decisions on behalf of the environment. This contradicts the findings from developed countries, where environmental champions and personal leadership are pointed to as crucial to environmental engagement ${ }^{(13)}$, particularly in management where the range of pro-environment action available is greater, and many lead to eco-savings with minimal investments- yet green marketing action require company consensus ${ }^{(14)}$. 
It is likely that marketing managers are struggling to close the gap between their personal behaviors and their managerial behaviors. Part of the problem can be attributed to the very hierarchical structure in many Egyptian organizations, particularly locally managed organizations, where decision- making is highly centralized ${ }^{(15-18)}$.

Table (7) shows that distribution of the studied cases according to organizational environmental behaviors were evaluated by asking marketing managers to indicate their degree of agreement or disagreement with 9 statements on five points liker scale. In all hotels, the most strongly disagree responses with a (50\%) response rate to the statements, environmental management marketing in hotels industry is a public relations invention to name cordial relation with stakeholders, where $(M=1.72)$ followed by (47.8) response rate to the statements, hotels occupancy levels are more important than environmentally issues, where $(M=1.57)$. while the response rate to the statements, governmental intervention is important to encourage hotels to be environmentally friendly was agree by $39.7 \%$ where $(\mathrm{M}=3.07)$, the most strongly agreed responses with a $15.2 \%$ to the statement a hotel should wait and see how competitors are benefiting before introducing environmental strategies where $(M=3)$ where $M=3$ followed by $13 \%$ to the statement, hotels don't have the right to damage the environmental just to satisfy their needs with $(M=2.74)$.

\section{CONCLUSION}

Green star activities and processes are somewhat different from eco-friendly hotel arrangements because eco-friendly hotels concern only subjects that protect the environment but do not much care about the hotel building, and some technical aspects. Now, in the world the numbers of green hotels are enormously increasing due to the fast global warming. All hotels have decided to be more careful.

\section{RECOMMENDATION}

1. The government should institute rewards to promote green practices in the hotel sector in Egypt especially in Alexandria city.

2. Training program, about environment especially about appropriate techniques for waste management should be organized.

3. employees should be Trained to make them fully understand the concept of environmental protection, in both work and living environment.

4. Consumers must recognize the fact that environment protection is to keep the last piece of clean land for our future generations.

\section{REFERENCES}

1. Das L. (2012) Green Marketing and its Impact in Global Business; International conference on technology and business management, p. 488-493.

2. Panitha p.and Mohd rasdi R. (2013) corporate social responsibility: Adoption of Green Marketing by Hotel Industry; Asian Social Science; Vol. g, No. 17, p. 79-93.

3. Chan, E.S.W. (2013) Managing green marketing: Hong Kong hotel managers perspective; International Journal of Hospitality Management 34, p. 442-461.

4. Muntean, A. and Stremtan, F. (2008). Green Marketing: a new challenge for Romanian organization. Tourism management, 14(2), 343-34.

5. Roberts, J.A. (1996). Green Consumers in the 1990s: profile and implications for advertising.

6. Song, H. J.; Lee, C.; Kang, S.k. and Boo, S. (2012): the effect of environmentally friendly perceptions on festival visitors decision- making process using an extended model of goal- directed behavior. Tourism management, 2012 (1-12).

7. Rudez, H. N. (2010). Integration of corporate social responsibility into loyalty programs in management, 16(1), 101-108.

8. Weissman A. (2013) "Green" marketing changes with new FTC guides; retrieved on 02/24/2014 from. http:// www.greensseal.org. 
9. Cary J.; Bhaskara S.and Polonsky M. (2004) Green Marketing and EMS Assessing potential consumer influence on EMS development in Fresh Food Chains; A report for the rural industries research and development corporation, RIRDC publication.

10. What is an environmental management system? (2014) Retrieved on 02/24/2014 from http://www.envronmental management system.com.au.

11. Cunha Lemos. A.D., and Giacomucci, a. (2002). Green procurement activities some environmental indicators and practical actions taken by industry and tourism. Environment and sustainable development1 (1), 59-72 http://dx.doi.org//10.1504//1JESD.2002.000.718.

12. Kasim, A. (2004). Socio-environmentally responsible hotel business: Do tourists to Penang, Island, and Malaysia care? Journal of hospitality and leisure marketing, 11(4),5-28

13. An derssor, L.M., and Bateman, T.S.(2000). Individual environmental initiative: championing natural environmental issues in U.S. business organization. Academy of Management Journal, 43(4),548-570.

14. Crane, A. (2000 a). Facing the backlash: Green marketing and strategic reorientation in the $1990 \mathrm{~s}$, Journal of strategic marketing, 8(3),277-296.

15. Attia , A.; Shankar Mahesh, M.N., and sing hapakdi, A.(1999). Marketing ethics: A comparison of American and middle-Eastern marketers. International business review, 8 (5-6),611-632

16. EL-sawah, S.E., Tharwat, A.A. and Rasmy ,M.H.(2008). A quantitative model of predict the Egyptian ERP implementation success index.

17. Rice, G. (2006a). Individual value, organizational context, and self-employee creativity: Evidence From Egyptian organizations. Journal of business research, 59(2),233-241.

18. Shalley, C. E; zhou, J. and old ham, G.R.(2004). The effects of personal and contextual characteristics on creativity, where should we go from here? Journal of management, 30(16), 933-958.

19. Rice, G. (2006b). Pro-environmental behavior in Egypt: Is there a role for Islamic environmental ethics? Journal of business ethics 65(4), 373-390.

20. Rivera, J. and Leon, p. (2005). Chief executive officers and voluntary environmental performance: Costa Rica's certification for sustainable tourism. Policy sciences, 38(2-3), 107-127.

21. Ham brick, D.C. and finkelstein, S. (1987). Managerial discretion: A bridge between polar views of organizational outcomes. Research in organizational behavior, 9. 369-406

22. Aragon-Correa, J.A.; Matias- Reche, F. and senise- barrio. M.E. (2004). Managerial discretion and corporate commitment to the natural environment. Journal of business research, 57(9), 964-975.
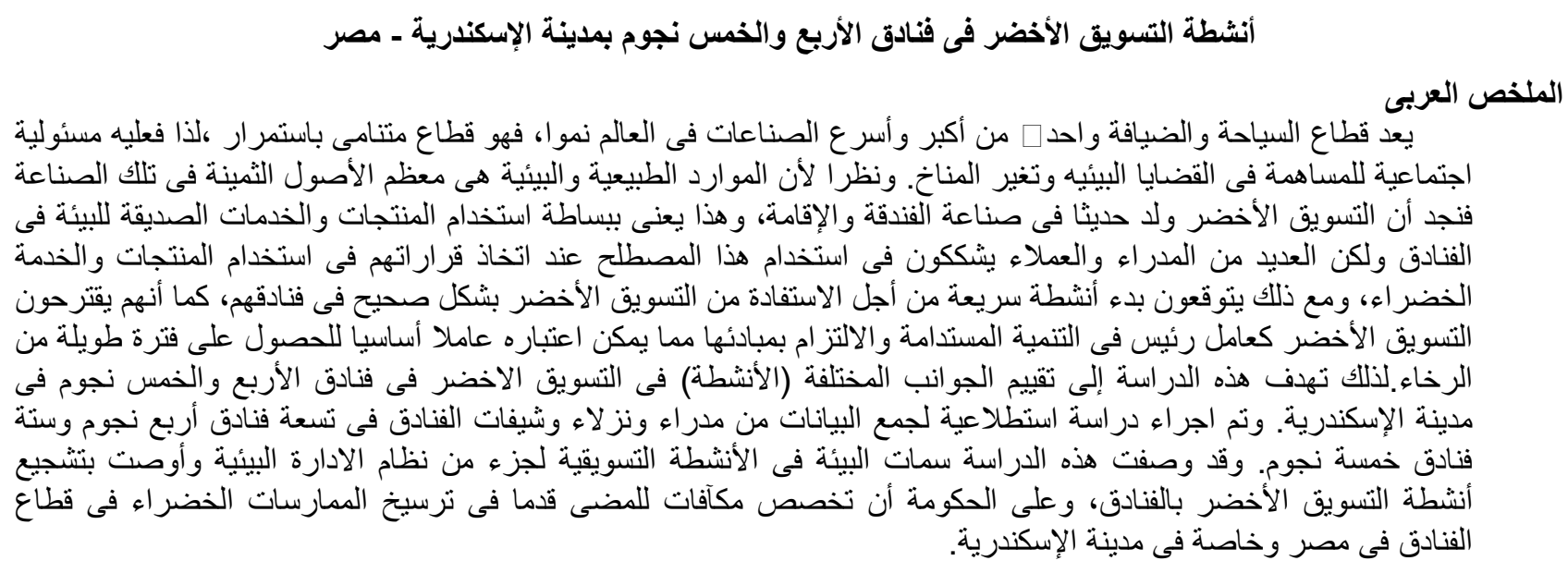